\title{
Paideusis
}

\section{A Reply to Forrest and Daniels}

\section{Kieran Egan}

Volume 12, Number 1, 1998

URI: https://id.erudit.org/iderudit/1073098ar

DOI: https://doi.org/10.7202/1073098ar

See table of contents

Publisher(s)

Canadian Philosophy of Education Society

ISSN

0838-4517 (print)

1916-0348 (digital)

Explore this journal

Cite this document

Egan, K. (1998). A Reply to Forrest and Daniels. Paideusis, 12(1), 65-68.

https://doi.org/10.7202/1073098ar

This document is protected by copyright law. Use of the services of Erudit (including reproduction) is subject to its terms and conditions, which can be viewed online.

https://apropos.erudit.org/en/users/policy-on-use/
This article is disseminated and preserved by Érudit.

Érudit is a non-profit inter-university consortium of the Université de Montréal, Université Laval, and the Université du Québec à Montréal. Its mission is to promote and disseminate research.

https://www.erudit.org/en/ 


\section{A Reply to Forrest and Daniels}

\section{Kieran Egan, Simon Fraser University}

Forrest begins her critique by saying that my main objection to the three old ideas-socializing, the academic shaping of the mind to perceive the truth about reality, and facilitating the development of a putative spontaneous psychological process-is that they are mutually incompatible. No, my main objection is that each is an inadequate educational idea; my second objection is that they are incompatible. A difficulty for making the kind of argument I launch, I suggest in the book, is that people are unable to think of education in any other terms, so they prefer the cognitive discomforts and logical absurdity to trying to find or face a new way of thinking about them. This is very much the point Plato made about his cave-dwellers who become so comfortable interpreting shadows that they are most reluctant to face what they are shadows of. The first response usually is that it is "a strength of education as an enterprise that its divergent assumptions continue to be articulated in educational debate," as Forrest puts it. But the same debates have been going on, fruitlessly it seems to me, for more than a hundred years. The same three ideas are assumed to be necessary to education-the only way to think about it-and the arguments have been simply assertions of a preference for some particular balance among the three. What "strength" this fruitless and sterile debating has delivered to education escapes me.

Is there a crisis in education? It depends what you mean . . etc. Frank Kermode suggested that "crisis" is the only form left to us to characterize the distinctiveness of the times we live in, having given up the older sense of chairos, of a connection with the sacred. So I talked of crisis in a fairly casual sense, mainly referring to all the reports that have insistently told us this. But also, I suppose, it is the inevitable sense of sadness at the massive waste of life that current formal educational institutions cannot avoid some responsibility for. That sense of waste, of course, gathers meaning only from some alternative sense of other possibilities. Most of us involved professionally in education have visions of what might be better. It is hard to sustain a Panglossian complacency, standing outside one's local high school at the close of any school day, and feel one is watching some institutional triumph of our times.

Why would I turn on my own arguments "in a typical postmodern gesture" when I have spent some time showing why I thought those routine postmodern gestures were parts of a clapped-out tradition that has aped Nietzsche's brilliant games without any of the brilliance and without recognizing they are games? I have tried to establish a more complex and sustainable conception of irony than appears in what used to be called, before he sensibly gave up on the term, the postmodern writings of Richard Rorty. I was a bit bewildered by Forrest's statement that I consider irony synonymous with skepticism. I do flog the reader through chunks of Kierkegaard in building the conception of irony, and Soren and I would both have a hard time taking that 'synonymous' on board. I guess I just do not follow Forrest's argument here. I really do not think I can be fairly accused of missing postmodernism's distinctive gesture of the ironic turn. I spend some time indicating why I think 
"pomo's" notion of irony is a rather sickly affair, in need of the bracing I claim it might have had if it had been truer to Socrates, from whose peculiar stance, via Quintilian and Seneca and Kierkegaard, came our modern sense of irony. I really only put the Schlegel in for fun, and I am sorry Forrest pays more attention to his nutty romanticism than to Kierkegaard's which, I think, is a much more interesting discussion. Perhaps I am jaded, or simple-minded, or oldfashioned confused, but I find stunningly boring "pomo's" attempts to squirm out of the problems their watery irony creates for their claims to have anything interesting to say about anything. They should recognize the only proper conclusion of their arguments is their silence. Still, I am sure it will soon be generally recognized as one of the drearier episodes in the decline of humanistic discourse in the West. No wonder scientists shake their heads in bemusement. Given this dyspeptic view, I would hardly be bothered to address "the postmodem critique of reason"; I was concerned to construct my own conception of irony and simply set it off against some others. In particular, I wanted to show that one need not give up on the whole enlightenment project, and so on, in order to see irony as a proper aim of education, and that, indeed, one can articulate a much richer conception of irony if one does not. "Pomo" came into it only because they keep warbling about irony, and I could not really go on without making some acknowledgement of that.

I suppose writers never recognize themselves in critiques; incessant adulation is a barely adequate response. Better to take Plato of the VIIth Letter's advice and realize that only a fool would try to put ideas into writing and expect them to be understood. Did I argue that the educational crisis is the effect of theorizing? Well, I suppose so. I remember writing that we often do things because of what we believe to be the case. I quoted Keynes to that effect, too. But I did not mean that the kinds of educational theories one finds in current textbooks were what caused the pathetic education so many children were receiving. I meant that we inherit a complex of ideas that shape our notions of what education is and what we should do to children in its name. These ideas are often quite unconsciously held, resting on presuppositions that are unrecognized, and they shape our practice. I have not been able to understand a word Hirst has to say about "practice" since he discovered it a while ago. In fact, I found him quite interesting until he discovered it. And how "theory" gets wrapped up in "disciplines," and how they tangle with "practice" just leaves me a tad too fatigued to follow. I just meant that what you think about something usually influences what you try to do about it. Somewhere in the text, or perhaps I cut it out for reasons of space, I contrast education's problems with institutions concerned with health. We would not think it admirable that divergent conceptions of health continued to be articulated in debates about healthcare, and we would not feel enthusiastic if we had radically divergent notions of what the aims of hospitals were. We might disagree about procedures and styles of health-care, but that is not the same as having quite different conceptions of health, as we do of education.

"Life results in conflicting needs, desires and interests... The reason the so-called 'old ideas' retain a certain purchase in educational debate is because each places its emphasis upon a different aspect of the educational contract." Well, yes, I know that. The first chapter is an argument about what is wrong with this situation. It is a bit rough to have the point you argue against at length 
cited back at you as refutation of your argument. "Each of these ideas acts as a check on the priorities of the others." Yes, yes; that's what I wrote. That's the cave-view I argue we need to turn from. And I thought my analysis was so neat and original, and everyone would say "Well done, lad. Now I see what the problem is. And do you have a solution?" Yes, there is the next bunch of chapters. They try to detail what I mean by "cognitive tools", but Forrest prefers to deal with what I might mean in the abstract, and by a brief reference to the "Conclusion"-but what about the bulk of the book? And why the difficulty in working out what kind of category a "kind of understanding", is? If all I had said about it were the items Forrest interrogates, I could sympathize with her critique at this point-but I do exemplify what I mean at considerable length through well over a hundred pages. Why not refer to that to see what I mean by a "kind of understanding"? I describe five of them-the bulk of the book. Ah, but I forgot to refer to Gilbert Ryle, and seem to be making the old "category mistake." (He mutters incoherently, making the sign to ward off the evil eye.)

It is, of course, proper to focus on what seems to be the bases on which the book's arguments are constructed, and Forrest kindly notes twice that particular parts would be worth reading the whole for. But I am not sure I would be bothered to read a book so riddled with fundamental errors. I concluded the book with the "lame boast" that I had brought educational thinking into the late nineteenth century, having argued that nearly all current educational discourse draws on only three ideas, the most recent of which was articulated in the eighteenth century. I guess all that was taken as window-dressing, perhaps appropriately. I did quote D.J. Enright's observation that one has to be careful dealing with irony because its guns point in all directions. I have clearly taken a few stray bullets from my own gun, not to mention Forrest's more deliberately aimed weapon. I am grateful for the care with which she has read the book.

Daniels requires less response as he seems to disagree with less of the argument-I have long admired his acute insight into things. But I want to squirm out from under one or two of his observations. He suggests what I have put together is an "epistemological theory." I do try to argue that we have been bedevilled, especially in education, by trying to reconcile a notion of the mind as an epistemological organ with notions of the mind as a psychological organ (and as a social organ, psycho-social organ, and so on, to Polonius-like elaboration and equivalent futility). I have, rather, been focusing on the mind as a peculiar organ most distinctively recognized in its absorption and use of what I call cognitive tools. The kinds of understanding are not epistemological categories, but are generated and supported by our learning to use particular tools, such as oral language, literacy, theoretic abstractions, extreme reflexiveness, and these break down into sets of sub-tools, like fantasy, metaphor, and story. I consider each of these in some detail and try to show how thinking of education as the accumulation of the maximum range of such conceptual tools gives us a picture of our enterprise that is at once rather novel, yet oddly familiar, and as liberating from the stale polemics that have dogged educational thinking since the foundation of the public schools in the nineteenth-century.

Daniels takes it that an ironist cannot have a theory. Of course, she or he can. Being Ironic, my theory implies, does not mean giving up on Philosophic understanding, and its insistently theory-building cognitive tools. 
Why can one only be a "critical thinker" at the Philosophic or Ironic layers? I see no reason why one cannot manage "critical thinking" tasks at any level. Perhaps Daniels is retaining too much of an old epistemological-hierarchy notion of education that this scheme is designed to destroy. He does seem to me to welcome it for some of the wrong reasons-almost as though it is good support for the epistemology-driven conception of education that he favours and I think should be discarded. His favourable words seem to me a bit like welcoming the wooden horse into the old citadel, but, crouched nervously in its belly, who am I to complain?

I suspect also that Daniels has an overly schematic sense of this schematic theory. He writes as though Ironic understanding is, indeed, like one of those Piagetian stages he compliments me for avoiding. The baby playing peekaboo is already developing a sense of irony. It is not something exclusively for the graduate student. These are not discrete chunks, as I try to emphasize in Chapter 6. The theory captures, I hope, rather more of the messy complexity of our mental experience than bas been common in psychological stage theories.

I think some of the issues raised in these thoughtful reviews might have benefited from a chapter I cut out of the book, thinking it rambled too much into epistemological matters that most educationalists would not be very captivated by. Anyone who is interested may find the chapter, and a bunch of other stuff, including more reviews, on my website at

http://www.educ.sfu.ca/people/faculty/kegan/ 